Review

\title{
Regulation of neuronal ion channels via P2Y receptors
}

\author{
Stefan G. Lechner \& Stefan Boehm \\ Institute of Pharmacology, Medical University of Vienna, Vienna, Austria
}

Received 8 September 2004; accepted in revised form 12 October 2004

Key words: G proteins, ligand-gated ion channels, $\mathrm{P} 2 \mathrm{Y}$ receptor, voltage-gated $\mathrm{Ca}^{2+}$ channel, voltage-gated $\mathrm{K}^{+}$channel, voltage-gated $\mathrm{Na}^{+}$channel

\begin{abstract}
Within the last 15 years, at least 8 different G protein-coupled P2Y receptors have been characterized. These mediate slow metabotropic effects of nucleotides in neurons as well as non-neural cells, as opposed to the fast ionotropic effects which are mediated by P2X receptors. One class of effector systems regulated by various G protein-coupled receptors are voltage-gated and ligand-gated ion channels. This review summarizes the current knowledge about the modulation of such neuronal ion channels via $\mathrm{P} 2 \mathrm{Y}$ receptors. The regulated proteins include voltage-gated $\mathrm{Ca}^{2+}$ and $\mathrm{K}^{+}$channels, as well as $N$-methyl-D-aspartate, vanilloid, and P2X receptors, and the regulating entities include most of the known P2Y receptor subtypes. The functional consequences of the modulation of ion channels by nucleotides acting at pre- or postsynaptic $\mathrm{P} 2 \mathrm{Y}$ receptors are changes in the strength of synaptic transmission. Accordingly, ATP and related nucleotides may act not only as fast transmitters (via P2X receptors) in the nervous system, but also as neuromodulators (via P2Y receptors). Hence, nucleotides are as universal transmitters as, for instance, acetylcholine, glutamate, or $\gamma$-aminobutyric acid.
\end{abstract}

\section{Introduction}

Many functional characteristics of neurons are similar or even identical to those of other cells, but there is one fundamental difference: The primary functions of neuronal cells are to receive, modify, and transmit messages. This flow of information occurs within one neuron as well as between neurons. Whether the neuronal communication is intra- or intercellular, it is always dependent on electrical activity which is provided by ligand- as well as voltagegated ion channels. With respect to electrical properties, different neurons are by far not equal but rather characterized by prototypical synaptic responses that are governed by the expression of a certain set of ion channels. Even within one nerve cell, the electrical properties are not fixed, but may change with time depending on the presence of neurotransmitters, hormones, or growth factors. The basis for changes in the electrical responsiveness of a neuron are alterations in the opening and closure of ion channels. Such changes are in many cases triggered by neurotransmitters that act via heptahelical transmembrane receptors typically linked to heterotrimeric G proteins [1].

Adenine and uridine nucleotides are present in all types of cells and are released in response to various stimuli [2]. Once in the extracellular space, they activate one or more

Correspondence to: Dr Stefan Boehm, Institute of Pharmacology, Medical University of Vienna, Waehringerstrasse 13a, 1090, Vienna, Austria. Tel: +43-1-427764146; Fax: +43-1-42779641; E-mail: stefan.boehm@ meduniwien.ac.at of at least 15 different membrane proteins which are categorized as $\mathrm{P} 2$ receptors. Alternatively, they are converted to other nucleotides or degraded down to nucleosides by different ectoenzymes [3]. The receptors for nucleosides are categorized as P1 receptors. Receptors for nucleotides comprise ionotropic $\mathrm{P} 2 \mathrm{X}$ and metabotropic $\mathrm{P} 2 \mathrm{Y}$ receptors. $\mathrm{P} 2 \mathrm{X}$ receptors are ATP-gated cation channels composed of presumably three subunits out of a repertoire of at least seven different proteins which all have two presumed transmembrane domains with large extracellular loops and intracellular $\mathrm{N}$ - and C-termini [4, 5]. $\mathrm{P} 2 \mathrm{Y}$ receptors, in contrast, are characterized by seven putative transmembrane domains typical of $G$ proteincoupled receptors. Currently, at least eight different subtypes have been identified ( $\mathrm{P} 2 \mathrm{Y}_{1}, 2,4,6,11,12,13,14$; [4, 6-8]. Thus, with respect to the modulation of ion channels, receptors for nucleotides may represent the regulated entity in the case of $\mathrm{P} 2 \mathrm{X}$ receptors, and they may also be the regulating entity in the case of P2Y receptors. This review focuses on the interactions between $\mathrm{P} 2 \mathrm{Y}$ receptors and both, ligand- as well as voltage-gated, ion channels and therefore deals with $\mathrm{P} 2 \mathrm{X}$ receptors in only a very few instances.

\section{Pharmacological and functional characteristics of P2Y receptors}

A considerable number of heptahelical receptors that can be activated by extracellular nucleotides have been 
cloned from various species. According to the structural classification of $\mathrm{P} 2$ receptors they were categorized as $\mathrm{P} 2 \mathrm{Y}$ receptors and numbered in chronologic order which led to the description of $\mathrm{P}_{2} \mathrm{Y}_{1}$ through $\mathrm{P} 2 \mathrm{Y}_{15}$ receptors [9]. However, some of the receptors provided with P2Y receptor numbers were subsequently identified as species homologues of other $\mathrm{P} 2 \mathrm{Y}$ receptors or as members of other families of $\mathrm{G}$ protein-coupled receptors [6]. The presumed $\mathrm{P} 2 \mathrm{Y}_{15}$ receptor is also activated by $\alpha$-ketoglutarate [10] and may thus not be a true member of the P2Y family. Accordingly, only eight different mammalian subtypes are currently viewed as members of the P2Y family, namely P2Y $1,2,4,6,11,12,13,14$ [4, 6-8].

These P2Y receptors are activated not only by ATP, but also by other naturally occurring nucleotides or nucleotide sugars, such as ADP, UTP, UDP, and UDP glucose [4, 6-8]. At $\mathrm{P}_{2} \mathrm{Y}_{1}$ receptors of various species, the rank order of agonist potency is 2-MeSADP $\geq 2$-MeSATP $>$ ADP $\geq$ ATP with uridine nucleotides being inactive. At $\mathrm{P} 2 \mathrm{Y}_{2}$ receptors, ATP and UTP are equipotent agonists, and ADP, UDP, or 2-methylthio derivatives have weak or no activity. $\mathrm{P}_{2} \mathrm{Y}_{4}$ receptors are activated by UTP, and the rat and mouse receptors are also activated by ATP, whereas the human receptors are antagonized by $\mathrm{ATP}$ [11]. At $\mathrm{P}_{2} \mathrm{Y}_{6}$ receptors, UDP is the most potent agonist and ADP, ATP or UTP are, if at all, only weak agonists. Human $\mathrm{P} 2 \mathrm{Y}_{11}$ receptors show the following rank order of agonist potency: ATP $\geq$ 2-MeSATP $>$ ADP, and the observed agonistic activity of UTP depends on the signalling cascade that is activated by the receptor [12]. The nucleotide selectivity of canine $\mathrm{P} 2 \mathrm{Y}_{11}$ receptors is 2-MeSATP $>$ ADP $>$ ATP [13]. At $\mathrm{P} 2 \mathrm{Y}_{12}$ receptors, 2-MesADP is much more potent as an agonist than ADP, and the efficacy of ATP is species-dependent with high intrinsic activity at rat but not at human receptors $[14,15] . \mathrm{P}^{2} \mathrm{Y}_{13}$ receptors are activated by 2-MesADP, ADP, and ATP, but the rank order of agonist potency is different for human, murine, and rat receptors [16-18]. The $\mathrm{P}_{2} \mathrm{Y}_{14}$ receptor is activated by various UDP sugars, but not by adenine or uridine nucleotides [8, 19].

According to the agonist profiles summarized above, $\mathrm{P} 2 \mathrm{Y}$ receptors can be characterized as receptors for purines $\left(\mathrm{P} 2 \mathrm{Y}_{1}, 11,12,13\right)$, for pyrimidines $\left(\mathrm{P} 2 \mathrm{Y}_{6}, 14\right)$, or for both types of nucleotides $\left(\mathrm{P}_{2} \mathrm{Y}_{2}, 4\right)$. In parallel, these receptors can be classified as receptors preferring nucleoside tri$\left(\mathrm{P} 2 \mathrm{Y}_{2,4}, 11\right)$ or diphosphates $\left(\mathrm{P} 2 \mathrm{Y}_{1,6}, 12,13,14\right)$. This latter categorization appears particularly important from a functional point of view, as extracellular nucleotides are released from a large variety of cells and rapidly converted by ectoenzymes [3]. The interconversion between different extracellular nucleotides is also a factor that needs to be taken into consideration, when $\mathrm{P} 2 \mathrm{Y}$ receptors are characterized by the application of various nucleotides. For instance, the triphosphate sensitivity of $\mathrm{P}_{2} \mathrm{Y}_{2}$ and 4 receptors can only be demonstrated unequivocally, if the conversion of nucleoside diphosphates to triphosphates is prevented [20]. Given these experimental difficulties with endogenous and exogenous agonistic nucleotides, the characterization of $\mathrm{P} 2 \mathrm{Y}$ receptors should preferably rely on the use of specific antagonists. A considerable number of compounds have been found to block P2Y receptors, but unfortunately the majority of antagonists is not sufficiently selective. For instance, the most widely used $\mathrm{P} 2$ receptor antagonists suramin and reactive blue 2 block not only a large number of $\mathrm{P} 2 \mathrm{X}$ and $\mathrm{P} 2 \mathrm{Y}$ receptors, but also unrelated receptors, such as NMDA receptors [21] and anion channels [22]. Nevertheless, for some P2Y receptor subtypes selective antagonists have been identified or developed. For instance, adenosine- $2^{\prime}$-phosphate- $5^{\prime}$-phosphate (A2P5P) and adenosine- $3^{\prime}$-phosphate- $5^{\prime}$-phosphate (A3P5P) were found to be partial agonists with low intrinsic activity at $\mathrm{P} 2 \mathrm{Y}_{1}$ receptors [23]. Derivatives thereof, such as $N^{6}$-methyldeoxyadenosine $3^{\prime}, 5^{\prime}$-biphosphate (MRS2179) or 2-chloro- $N^{6}$-methyldeoxyadenosine 3',5'-biphosphate (MRS 2216) are selective and competitive antagonist at $\mathrm{P} 2 \mathrm{Y}_{1}$ receptors with nanomolar affinity [24]. The $\mathrm{P}_{2} \mathrm{Y}_{12}$ receptor has been identified as the target of metabolites of the well-known antithrombotic drugs ticlopidine and clopidogrel [25]. ATP derivatives, such as AR-C69931MX, are also antagonists with high affinity at this receptor subtype and were developed for clinical use in patients with acute coronary syndromes [26]. Unfortunately, this latter agent is not absolutely selective for $\mathrm{P} 2 \mathrm{Y}_{12}$, but also blocks $\mathrm{P} 2 \mathrm{Y}_{13}$ receptors. However, at $\mathrm{P} 2 \mathrm{Y}_{12}$ this agent is a competitive, and at $\mathrm{P}_{2} \mathrm{Y}_{13}$ a non-competitive, antagonist [17]. Recently, insurmountable antagonists with nanomolar affinities for $\mathrm{P}_{2} \mathrm{Y}_{6}$ receptors, but no activity at $\mathrm{P} 2 \mathrm{Y}_{1,2,4}$ and $\mathrm{P} 2 \mathrm{Y}_{11}$ receptors, such as 1,4-di-[(3-isothiocyanato phenyl)-thioureido]butane (MRS 2578), have been developed [27].

$\mathrm{P} 2 \mathrm{Y}_{1}, 2,6,13$, and $\mathrm{P}_{2} \mathrm{Y}_{14}$ are widely expressed in a variety of tissues including the nervous system, whereas $\mathrm{P}_{2} \mathrm{Y}_{4}$ and 11 show a restricted expression pattern that excludes neuronal tissues $[4,9,19,28]$. P2 $Y_{1}$ mRNA and protein is found at high levels in many regions of the central nervous system including the cerebral and cerebellar cortices, hippocampus, caudate nucleus, putamen, globus pallidus and midbrain [29-31]. In in situ hybridizations of brain sections, the expression pattern of $\mathrm{P} 2 \mathrm{Y}_{12}$ was consistent with a predominantly glial localization $[25,32] . \mathrm{P}_{2} \mathrm{Y}_{13}$ mRNA was also detected in different brain regions, such as the thalamus, caudate nucleus, substantia nigra, hippocampus and cerebellum [28].

In heterologous expression systems, all P2Y receptor subtypes were found to mediate increases in inositol phosphates (IPs) or in intracellular $\mathrm{Ca}^{2+}$, thus indicating that they are coupled to phospholipase C (PLC) [4, 9, 28, 32]. The $\mathrm{P} 2 \mathrm{Y}$ receptor-mediated increases in IPs did not involve pertussis toxin-sensitive $G$ proteins in the cases of $P 2 Y_{1}, 6$ and 11 , but were to various degrees reduced by that bacterial toxin in the cases of $\mathrm{P}_{2} \mathrm{Y}_{2}$ and $\mathrm{P} 2 \mathrm{Y}_{4}$ [4]. With $\mathrm{P} 2 \mathrm{Y}_{12}, 13$ and $\mathrm{P} 2 \mathrm{Y}_{14}$ receptors, nucleotide-dependent increases in IPs were only detected when the receptors were co-expressed together with either $\mathrm{G \alpha}_{16}$ or chimaeric $\mathrm{G}$ protein $\alpha$ subunits, and the actions mediated by these receptors were pertussis toxin-sensitive and thus mediated by inhibitory $\mathrm{G}$ proteins $[19,28]$. $\mathrm{P} 2 \mathrm{Y}_{11}$ mediates increases in cyclic AMP in addition to the rises in IPs [9, 33], and the coupling of this receptor to different effector systems 
displays different agonist sensitivities [12]. $\mathrm{P} 2 \mathrm{Y}_{12}$ and $\mathrm{P} 2 \mathrm{Y}_{13}$ mediate a pertussis toxin-sensitive inhibition of adenylyl cyclase $[25,28]$, and in pertussis toxin-treated cells, $\mathrm{P} 2 \mathrm{Y}_{13}$ mediates a stimulation of adenylyl cyclase [28].

\section{Regulation of neuronal ion channels via $\mathrm{G}$ protein-coupled receptors}

Ion channels and $\mathrm{G}$ protein-coupled receptors of neurons are encoded by several hundred genes, and the list is still growing. Accordingly, it is impossible to summarize all the interactions between them, and this chapter highlights only a few examples which are important for the understanding of mechanisms that may link $\mathrm{P} 2 \mathrm{Y}$ receptors to various ion channels. The ion channels that will be described below include ligand-gated ion channels as well as voltage-gated $\mathrm{Na}^{+}, \mathrm{Ca}^{2+}$ and $\mathrm{K}^{+}$channels.

Currently, at least nine different types of pore forming subunits of voltage-gated $\mathrm{Na}^{+}$channels are known and they contain several sites that may become phosphorylated by protein kinases A and C. On a functional level, phosphorylation by both kinases leads to reduced $\mathrm{Na}^{+}$currents [34]. In accordance with this, $D_{1}$-like receptors were found to reduce $\mathrm{Na}^{+}$currents in hippocampal neurons via protein kinase A [35], and this effect was enhanced at hyperpolarized membrane potentials and by co-activation of protein kinase $\mathrm{C}$ [36]. Moreover, activation of muscarinic receptors reduced $\mathrm{Na}^{+}$currents via protein kinase $\mathrm{C}$ in hippocampal [37] and neocortical neurons [38]. A similar effect was observed in neurons of the prefrontal cortex when $5-\mathrm{HT}_{2}$ receptors were activated [39]. In sensory neurons, however, hyperalgesic agents increase currents through tetrodotoxin-resistant $\mathrm{Na}^{+}$channels [40], and this effect was again mediated by protein kinase A [41]. Thus, several types of $\mathrm{G}$ protein-coupled receptors were found to modulate $\mathrm{Na}^{+}$channels and increases as well as decreases in currents were observed depending on the types of neurons that were investigated.

Voltage-activated $\mathrm{Ca}^{2+}$ channels are classified by the genes encoding the pore forming $\alpha_{1}$ subunits, and one can discern between three subfamilies named $\mathrm{Ca}_{\mathrm{V}} 1$ to $\mathrm{Ca}_{\mathrm{V}} 3$. Members of all three families contribute to the voltagegated $\mathrm{Ca}^{2+}$ currents found in neurons. Channels formed by $\mathrm{Ca}_{\mathrm{V}} 1$ proteins mediate L-type currents, those containing, $\mathrm{Ca}_{\mathrm{V}} 2.1$ to $\mathrm{Ca}_{\mathrm{V}} 2.3$ mediate P/Q-, N- and R-type currents, and those harbouring $\mathrm{Ca}_{\mathrm{V}} 3$ subunits mediate T-type $\mathrm{Ca}^{2+}$ currents [42]. While channels providing N- and P/Q-type currents are involved in excitation secretion coupling in most nerve terminals, the other channels are rather found at somatodendritic regions of neurons [42]. Modulation via $G$ protein-coupled receptors has been described for an exhaustive number of neurotransmitters and for all types of voltage-gated $\mathrm{Ca}^{2+}$ currents [43-46]. The modulation of L-type currents is either facilitatory or inhibitory and is in most cases mediated by diffusible second messengers and protein kinases [45]. In contrast, the modulation of $\mathrm{N}$ and $\mathrm{P} / \mathrm{Q}$-type channels is almost exclusively inhibitory and is frequently independent of diffusible second messengers and protein kinases [43, 44], although there are some exceptions to this rule $[47,48]$. The pathway that excludes diffusible second messengers is membrane-delimited and leads to a voltage-dependent inhibition of currents as revealed by the fact that large depolarisations attenuate the inhibition. This inhibition is in most, but not all, cases abolished by pertussis toxin [43], and is based on a direct interaction between $\mathrm{G}$ protein $\beta \gamma$ subunits and $\mathrm{Ca}^{2+}$ channel proteins $[44,46]$. Pathways involving the synthesis of diffusible second messengers most commonly lead to a voltage-independent reduction of $\mathrm{Ca}^{2+}$ currents and have been reported to involve $\alpha$ subunits of the $G_{\mathrm{q} / 11}$ protein family [49, 50].

The superfamily of voltage-dependent $\mathrm{K}^{+}$channels comprises many more members than those of $\mathrm{Na}^{+}$or $\mathrm{Ca}^{2+}$ channels, and the $\mathrm{K}^{+}$channels are, in addition, very heterogeneous [51]. Although quite a number of these various $\mathrm{K}^{+}$channels were reported to be modulated by neurotransmitters, the most intensively studied examples of $\mathrm{K}^{+}$channel regulation via $\mathrm{G}$ protein-coupled receptors are inward rectifier (Kir) channels and KCNQ channels which are now classified as $\mathrm{K}_{\mathrm{V}} 7$ family [51]. In a variety of neurons, several neurotransmitters were found to cause hyperpolarizations by activating inwardly rectifying $\mathrm{K}^{+}$ currents via receptors coupled to pertussis toxin-sensitive $\mathrm{G}$ proteins. These effects were found to involve proteins of the Kir3 family and $G$ protein $\beta \gamma$ subunits [52]. However, the regulation of $\mathrm{G}$ protein-coupled inwardly rectifying $\mathrm{K}^{+}$ (GIRK) channels depends not only on $\beta \gamma$ subunits, but also on other proteins and second messengers. G Protein $\alpha$ subunits may act as donors for $\beta \gamma$, on one hand, and directly block GIRK channels [53], on the other hand. Furthermore, the kinetics of the gating of GIRKs is determined by all three parameters, receptor type, G protein $\alpha$, and $G$ protein $\beta \gamma$ subunits [54]. In addition, regulators of $G$ protein signalling also determine the kinetics of GIRK activation [55]. Moreover, GIRK channels are activated by phosphatidylinositol 4,5-bisphosphate $\left(\mathrm{PIP}_{2}\right)$ [56], and the levels of $\mathrm{PIP}_{2}$ are also regulated via $\mathrm{G}$ protein-coupled receptors and PLC [57]. As a consequence, activation of receptors linked to $G_{\mathrm{q}}$ proteins may also contribute to the regulation of GIRK channels [58]. Finally, activation of Gs coupled receptors was reported to enhance currents through GIRK channels [59].

A number of neurotransmitters were found to depolarize neurons by reducing $\mathrm{M}$-type $\mathrm{K}^{+}$currents $\left(I_{\mathrm{M}}\right)$ which are believed to be mediated by KCNQ channels [60]. These ion channels are opened in the subthreshold voltage range for action potentials and become completely activated when neurons are further depolarized. Hence, activated KCNQ channels keep neurons polarized, and closure of these ion channels causes depolarization and increased action potential discharge $[61,62]$. The inhibition of $I_{\mathrm{M}}$ via $M_{1}$ muscarinic acetylcholine receptors involves $\alpha_{q}$ subunits of heterotrimeric GTP binding proteins [63], and a reduction in $\mathrm{PIP}_{2}$ through an activation of phospholipase $\mathrm{C}$ [64]. The inhibition of $I_{\mathrm{M}}$ via bradykinin $\mathrm{B}_{2}$ receptors, in contrast, involves $G$ proteins of the $G_{q}$ family, most likely $\mathrm{G}_{11}$, and rather $\alpha$ then $\beta \gamma$ subunits $[50,63,65]$. Via these 
$\mathrm{G}$ proteins, phospholipase $\mathrm{C}-\beta 4$ is stimulated [66] to mediate the synthesis of IP3, which then causes liberation of $\mathrm{Ca}^{2+}$ from intracellular stores [67]. Cytosolic $\mathrm{Ca}^{2+}$ concentrations in the sub- to low micromolar range directly block $\mathrm{K}_{\mathrm{M}}$ channels [68].

The nicotinic acetylcholine receptor as a prototypical ligand-gated ion channel has been shown to be modulated via a variety of $G$ protein-coupled receptors, and receptor activation was found to either enhance or reduce the function of that ion channel [69-73]. The inhibition of currents through nicotinic acetylcholine receptor was suggested to be mediated by an inhibition of proteinkinase A-dependent phosphorylation [73]. The enhancement of these currents involved pertussis toxin-sensitive $\mathrm{G}$ proteins, but not altered phosphorylation [72]. A direct interaction between $G$ protein subunits and ligand-gated ion channels has been demonstrated for glycine receptors. Currents through these ion channels were enhanced by free $G$ protein

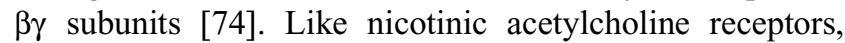
glycine receptors were found to be inhibited by prostaglandin E2, and this effect involves proteinkinase A-mediated phosphorylation [75]. Another ligand-gated ion channel, the glutamatergic NMDA receptor, is also regulated by phosphorylation secondary to the activation of $G$ proteincoupled receptors. In that case, the activation of muscarinic acetylcholine receptors enhanced NMDA receptor currents via protein kinase $\mathrm{C}$ and non-receptor tyrosine kinase [76]. However, $\mathrm{D}_{2}$-like receptors reduce currents through NMDA receptors via transactivation of receptor tyrosine kinases [77]. In addition, $\mathrm{D}_{1}$ receptors may also directly interact with NMDA receptors [78]. For the inhibitory transmitter GABA, a direct interaction of the ionotropic $\mathrm{GABA}_{\mathrm{A}}$ receptors and the metabotropic $\mathrm{GABA}_{\mathrm{B}}$ receptor has been reported to regulate receptor trafficking [79]. Hence, a multitude of mechanisms provide functional links between $\mathrm{G}$ protein-coupled receptors and various ligand-gated ion channels.

\section{Regulation of $\mathrm{Na}^{+}$channels via $\mathrm{P} 2 \mathrm{Y}$ receptors}

ATP was found to enhance or inhibit tetrodotoxin-sensitive as well as -insensitive voltage-gated sodium channels in rat dorsal root ganglion neurons [80] and in a neuronal hippocampal cell line [81]. However, these effects did not appear to involve $\mathrm{G}$ proteins and were rather mediated by a direct interaction of ATP with the sodium channel. No additional evidence for a modulation of neuronal $\mathrm{Na}^{+}$ channels via P2Y receptor could be found in the literature.

\section{Regulation of $\mathrm{Ca}^{2+}$ channels via $\mathrm{P} 2 \mathrm{Y}$ receptors}

\section{Native receptors}

Since Dunlap and Fischbach [82, 83] first described transmitter-induced inhibition of voltage-gated calcium channels, a plethora of other neurotransmitters and hormones that exert their actions via $G$ protein-coupled receptors have been shown to inhibit native $\mathrm{Ca}^{2+}$ currents (see above). First direct evidence for a nucleotide regulation of voltage-gated calcium channels was presented by Diverse-Pierluissi et al. [84], who showed that ATP and ADP, but not UTP, induce a pertussis toxin-sensitive inhibition of voltage-gated $\mathrm{Ca}^{2+}$ currents in bovine adrenal chromaffin cells. Subsequent studies by several other groups [85-87] corroborated these results, and further showed that this reduction of calcium current amplitudes was voltage-dependent, antagonized by reactive blue 2 and due to an inhibition of $\mathrm{N}$ - and P/Q-type calcium channels. Similar results were obtained in rat adrenal chromaffin cells, where ATP also inhibited voltage-gated $\mathrm{Ca}^{2+}$ currents in a PTX-sensitive manner and this effect was also antagonized by reactive blue 2 [88]. Another ATPinduced inhibition of $\mathrm{Ca}^{2+}$ currents, which was PTXinsensitive and voltage-dependent, was observed in frog sympathetic neurons [89]. In NG108-15 mouse neuroblastoma $\times$ rat glioma cells, not only adenine nucleotides, but also UTP and UDP, inhibited whole-cell $\mathrm{Ca}^{2+}$ currents [90], with the uridine nucleotides being even more potent agonists than the adenine nucleotides. In this case, not only an inhibition of N-type channels was responsible for the reduction of voltage-gated $\mathrm{Ca}^{2+}$ currents, but also L-type calcium channels were inhibited. Interestingly, only the $\mathrm{N}$-type channel inhibition was PTX-sensitive, while currents through L-type channels were still modulated after PTX treatment. However, it remained unclear whether these two effects were mediated by two different receptor subtypes or by a single receptor that coupled to multiple $G$ proteins.

More recently, several other examples for $\mathrm{Ca}^{2+}$ channel modulation via endogenous $\mathrm{P} 2 \mathrm{Y}$ receptors were reported. Vartian and Boehm [91] found that adenosine nucleotides inhibited voltage-gated $\mathrm{Ca}^{2+}$ currents in $\mathrm{PC} 12$ cells via a voltage-dependent and PTX-sensitive mechanism, but at that time the pharmacological profile of the receptor involved did not correspond to any of the known P2Y receptors. However, in subsequent studies the receptor responsible for this inhibition of voltage-gated $\mathrm{Ca}^{2+}$ currents in PC12 cells could be identified as the $\mathrm{P} 2 \mathrm{Y}_{12}$ receptor [92, 93]. In hamster submandibular neurons, the $\mathrm{P}_{2} \mathrm{Y}_{2}$ receptor was shown to mediate a voltage-dependent and PTX-sensitive inhibition of voltage-gated $\mathrm{Ca}^{2+}$ currents [94]. Moreover, $\mathrm{P} 2 \mathrm{Y}_{1}$ receptors in rat dorsal root ganglion neurons [95] and $\mathrm{P}_{2} \mathrm{Y}_{12}$ receptors in rat sympathetic neurons [96] were both shown to mediate a voltagedependent and pertussis toxin-sensitive inhibition of N-type calcium channels.

However, not only inhibitory effects of nucleotides on $\mathrm{Ca}^{2+}$ channels have been observed. ATP has also been shown to increase calcium currents in rat cardiac cells [97] and in hippocampal neurons [98]. Unfortunately, the signalling cascades involved in these effects have not been elucidated in detail.

\section{Recombinant receptors}

Based on their findings that UTP activates pertussis toxinsensitive as well as -resistant pathways in NG108-15 
neuronal hybrid cells [90, 99], Alexander Filippov, Eric Barnard, David Brown and collaborators extended their investigations on the coupling of $\mathrm{P} 2 \mathrm{Y}$ receptors to neuronal ion channels by using rat superior cervical ganglion neurons as an expression system for molecularly defined receptor subtypes. All of the $\mathrm{P} 2 \mathrm{Y}$ receptors that were investigated $\left(\mathrm{P} 2 \mathrm{Y}_{1}, 2,4,6,12\right)$ did couple to voltage-gated $\mathrm{Ca}^{2+}$ channels. As expected for a $\mathrm{G}_{\mathrm{i} / \mathrm{o}}$ coupled receptor, the inhibition of voltage-gated $\mathrm{Ca}^{2+}$ currents by $\mathrm{P}_{2} \mathrm{Y}_{12}$ was voltage-dependent and PTX-sensitive, and thus appeared to involve only the membrane-delimited pathway [14]. By contrast, the inhibition of voltage-gated $\mathrm{Ca}^{2+}$ currents mediated by $\mathrm{P}_{2} \mathrm{Y}_{1,2,4}$ and ${ }_{6}$ included two components: (1) the voltage-dependent and PTX-sensitive membranedelimited pathway as well as a (2) PTX-resistant component. The $\mathrm{P} 2 \mathrm{Y}_{2}$ receptor-mediated inhibition included a voltage-dependent and PTX-sensitive component, on one hand, and a voltage-independent and PTX-resistant component, on the other hand [100]. By contrast, when $\mathrm{P}_{2} \mathrm{Y}_{6}$ [101] or $\mathrm{P}_{2} \mathrm{Y}_{1}[102,103]$ were overexpressed, the pertussis toxin-resistant component appeared to be voltage-dependent, since it was facilitated by a large depolarizing prepulse. Interestingly, the authors found that the inhibition mediated by the $\mathrm{P}_{2} \mathrm{Y}_{6}$ receptor is much more pronounced in perforated patch (73\%) as compared to whole-cell (53\%) recordings. Moreover, the inhibition observed in the perforated-patch configuration was hardly altered by PTX, while in whole-cell recordings it was reduced by $60 \%$ after treatment with this toxin. Similar results were obtained when $\mathrm{P}_{2} \mathrm{Y}_{4}$ receptors were overexpressed [104]. In that case almost no inhibition $(\sim 10 \%)$ was observed in the disrupted whole-cell mode, while currents recorded in the perforated-patch mode were reduced by $\sim 45 \%$ in a PTX-sensitive and voltage-dependent manner. Taken together, these findings indicate that even the membranedelimited, PTX-sensitive pathway may require a soluble co-factor, and that a modulation of voltage-gated $\mathrm{Ca}^{2+}$ currents should rather be investigated in the perforatedpatch than the whole-cell mode of the patch clamp technique. Unfortunately, most of our current knowledge concerning the regulation of neuronal $\mathrm{Ca}^{2+}$ channels via $\mathrm{P} 2 \mathrm{Y}$ and other $\mathrm{G}$ protein-coupled receptors stems from whole-cell experiments only.

\section{Regulation of $\mathrm{K}^{+}$channels by $\mathrm{P} 2 \mathrm{Y}$ receptors}

\section{Native receptors}

Besides voltage-gated $\mathrm{Ca}^{2+}$ channels, a variety of $\mathrm{K}^{+}$ channels have consistently been shown to be modulated by nucleotides. One of the first examples was the inhibition of $I_{\mathrm{M}}$ by UTP [105] and ATP [106] in bullfrog sympathetic neurons. Although the receptors responsible for these effects remained unknown at that time, the authors could subsequently show that $I_{\mathrm{M}}$ inhibition by nucleotides involved a $G$ protein $[107,108]$. Only a few years later, after the cloning of the first $\mathrm{G}$ protein-coupled nucleotide receptors, Filippov et al. [99] could demonstrate that activation of the PLC-linked $\mathrm{P}_{2} \mathrm{Y}_{2}$ receptor in NG108-15 neuroblastoma $\times$ glioma hybrid cells led to an inhibition of native $I_{\mathrm{M}}$. Subsequently, several other groups could also observe an inhibition of $I_{\mathrm{M}}$ mediated by native P2Y receptors. In rat superior cervical ganglion neurons, a uridine nucleotide preferring receptor, most likely $\mathrm{P}_{2} \mathrm{Y}_{6}$, was reported to mediate an inhibition of $I_{\mathrm{M}}$ [109]. The signalling cascade underlying this inhibition included activation of PLC, generation of $\mathrm{IP}_{3}$, and release of $\mathrm{Ca}^{2+}$ from intracellular stores [110]. In rat thoracolumbar sympathetic neurons [111], UTP and UDP reduced $I_{\mathrm{M}}$ in cultures isolated from 9- to 12-day-old rats, but not in cultures prepared from newborn animals. More recently, Meng et al. [112] could show that the nucleotide induced inhibition of $I_{\mathrm{M}}$ in bullfrog sympathetic neurons is mediated by a $\mathrm{P} 2 \mathrm{Y}$ receptor, most likely $\mathrm{P}_{2} \mathrm{Y}_{4}$, as suggested by the observed rank order of agonist potencies.

In addition to $I_{\mathrm{M}}$ modulation, several other neuronal potassium channels were also found to be modulated by nucleotides. In a series of papers published in the mid nineties, Ikeuchi and Nishizaki described an outwardly rectifying potassium current activated by nucleotides. The current was found in various regions of the rat brain, including striatal neurons [113], inferior colliculus neurons [114], superior colliculus neurons [115], cerebellar neurons [116] and in hippocampal neurons [117]. Interestingly, although the current that was induced seemed to be the same in all these studies, the signal transduction mechanisms, as well as the receptor subtypes involved in channel activation seemed to differ between the various regions of the brain that were investigated. Responses that were induced by ATP in striatal neurons and by adenosine in superior colliculus and hippocampal neurons involved a diffusible second messenger and protein kinase $\mathrm{C}$, as could be shown by single channel recordings from cell-attached patches and by using the protein kinase $\mathrm{C}$ inhibitor GF109203X, respectively. By contrast, the actions of ADP in inferior colliculus neurons were membrane delimited, presumably based on a direct interaction of $\beta \gamma$ subunits of a PTX-insensitive G protein with the channel protein, as could be shown by single channel recordings from outside-out patches.

In rat hippocampal neurons, ATP was also reported to inhibit a voltage-gated $\mathrm{K}^{+}$channel [118]. UTP was as potent as ATP, and ADP and $\alpha, \beta$-methylene ATP also inhibited the outward current. More recently, another voltage-gated potassium channel, a fast delayed inward rectifier, in Xenopus spinal neurons was found to be inhibited by adenine and uridine nucleotides [119]. Since a much larger proportion of the neurons responded to ADP, but not to ATP or UTP, the authors speculated about the presence of two different $\mathrm{P} 2 \mathrm{Y}$ receptor subtypes, one mediating the effects of the triphosphates and the other mediating the effects of ADP.

\section{Recombinant receptors}

The potassium channels that have been studied most extensively with respect to their modulation by heterolo- 
gously expressed P2Y receptors are the KCNQ channels and the GIRKs. Among the receptors that were investigated, the $\mathrm{G}_{\mathrm{q} / 11}$ coupled receptors $\mathrm{P} 2 \mathrm{Y}_{1,2,4}$ and $\mathrm{P} 2 \mathrm{Y}_{6}$, when expressed in rat superior cervical ganglion neurons, all inhibited the $I_{\mathrm{M}}$ in a PTX-resistant manner $[100,101,103$, 104]. However, when the $P 2 Y_{12}$ receptor was expressed in these neurons, no inhibition of $I_{\mathrm{M}}$ by nucleotides could be observed [14]. When rat GIRK1 and GIRK2 (Kir3.1 and 3.2 subunits) were co-expressed, 2MeSADP and 2MeSATP, two potent $\mathrm{P} 2 \mathrm{Y}_{12}$ receptor agonists, evoked a $\mathrm{K}^{+}$current through GIRK channels. This is in accordance with the general concept that $\mathrm{G}_{\mathrm{i} / \mathrm{o}}$ coupled receptors mediate an activation of GIRK channels. A more unexpected finding was that the $\mathrm{G}_{\mathrm{q} / 11}$-linked $\mathrm{P} 2 \mathrm{Y}_{1}$ receptor, when co-expressed with Kir3.1 and 3.2 subunits instead of $\mathrm{P} \mathrm{Y}_{12}$, also produced a PTX-sensitive activation of GIRK. This further supports the idea that a single P2Y receptor may couple to multiple G proteins. However, with $\mathrm{P} 2 \mathrm{Y}_{1}$, the fast activation was followed by a slower, but almost complete inactivation of the current in the continued presence of the agonist, an effect that has previously been observed when rat $\mathrm{P} 2 \mathrm{Y}_{2}$ receptors were expressed together with GIRK1/4 in Xenopus oocytes [120]. Similar results were also obtained with the mouse $\mathrm{P}_{2} \mathrm{Y}_{2}$ receptor, but not with human $\mathrm{P}_{2} \mathrm{Y}_{6}$, when expressed together with GIRK channels in Xenopus oocytes [121].

\section{Regulation of ligand-gated ion channels by P2Y receptors}

\section{Native receptors}

In neurons, nucleotides can act not only on voltage-gated, but also on ligand-gated ion channels. In layer $\mathrm{V}$ pyramidal neurons of the rat prefrontal cortex, adenine and uridine nucleotides, presumably acting on $\mathrm{P}_{2} \mathrm{Y}_{2}$ receptors, were found to enhance currents elicited by $N$ methlyl-D-aspartate (NMDA) [122]. By contrast, ADP- $\beta S$, a potent $\mathrm{P} 2 \mathrm{Y}_{1}$ receptor agonist, inhibited currents through NMDA receptors [123] in the same cells. Since this inhibition was antagonized by PPADS and MRS2179, an involvement of the $\mathrm{P}_{2} \mathrm{Y}_{1}$ receptor seemed most likely. In addition, ATP was found to directly inhibit NMDA receptors independently of $\mathrm{G}$ proteins and, therefore, not by activation of P2Y receptors. This latter inhibition was revealed to involve a direct binding of the nucleotide to the glutamate-binding pocket of the NR2B subunit of NMDA receptors [124].

Another ligand-gated ion channel that was found to be modulated by nucleotides is the vanilloid receptor 1 (VR1). In rat dorsal root ganglion neurons, capsaicin-evoked currents through VR1 were enhanced by the application of nucleotides [125]. This nucleotide-induced potentiation was abolished by application of calphostin $\mathrm{C}$, a potent protein kinase $\mathrm{C}$ inhibitor, and was mimicked by phorbol esters, thus suggesting that a $\mathrm{P} 2 \mathrm{Y}$ receptor linked to protein kinase $C$ via $G_{q / 11}$ proteins was involved. Considering the observed rank order of agonist potencies, the $\mathrm{P}_{2} \mathrm{Y}_{1}$ receptor was considered to be the most likely candidate. However, more recently the same group could show that the ATPinduced potentiation can also be observed in dorsal root ganglion neurons of $\mathrm{P} 2 \mathrm{Y}_{1}$-deficient mice [126]. Moreover, in in situ hybridizations rat dorsal root ganglion neurons were found to co-express VR1 and $\mathrm{P}_{2} \mathrm{Y}_{2}$ mRNA, but not P2 $Y_{1}$ mRNA. UTP was reported to be as potent an agonist as ATP, and suramin (which blocks $\mathrm{P}_{2} \mathrm{Y}_{2}$ but not $\mathrm{P}_{2} \mathrm{Y}_{4}$ ) abolished the potentiation by UTP. Taken together, these results indicated that it was rather the $\mathrm{P}_{2} \mathrm{Y}_{2}$ than the $\mathrm{P}_{2} \mathrm{Y}_{1}$ receptor that mediated the effects of nucleotides on $\mathrm{VR}_{1}$ in mouse and rat DRG neurons.

\section{Recombinant receptors}

In addition to the above effects obtained with native P2Y receptors in primary neuronal cell cultures, akin results were also obtained when P2Y receptors were heterologously expressed in Xenopus oocytes. When co-expressed together with the $\mathrm{P} 2 \mathrm{X}_{1}$ receptor, activation of both, $\mathrm{P} 2 \mathrm{Y}_{1}$ and $\mathrm{P}_{2} \mathrm{Y}_{2}$, caused a significant potentiation of the $\alpha, \beta$-MeATP-induced current through P2 $\mathrm{X}_{1}$ [127].

\section{Functional consequences of neuronal ion channel regulation via $\mathrm{P} 2 \mathrm{Y}$ receptors}

The effects of P2Y receptor activation on neuronal ion channels that have been observed most consistently and frequently are (1) inhibition of voltage-activated $\mathrm{Ca}^{2+}$ currents, (2) activation of $\mathrm{Ca}^{2+}$-dependent $\mathrm{K}^{+}$channels or GIRKs, and (3) inhibition of $I_{\mathrm{M}}$. Voltage-gated $\mathrm{Ca}^{2+}$ channels, in particular $\mathrm{N}$ - and $\mathrm{P} / \mathrm{Q}$-type channels, are located at presynaptic nerve terminals and link invading action potentials to transmembrane $\mathrm{Ca}^{2+}$ influx and ensuing vesicle exocytosis. Accordingly, the modulation of these ion channels via $G$ protein-coupled receptors will lead to changes in transmitter release [128]. The kinetics of presynaptic action potentials are shaped by voltageactivated and $\mathrm{Ca}^{2+}$-dependent $\mathrm{K}^{+}$channels, and modulation of these channels via $\mathrm{G}$ protein-coupled receptors can also lead to changes in vesicle exocytosis [129, 130]. In contrast to these $\mathrm{K}^{+}$channels, inwardly rectifying $\mathrm{K}^{+}$channels including GIRKs are hardly found at presynaptic nerve terminals and are generally not believed to directly contribute to transmitter release [129, 131]. With respect to KCNQ channels, which mediate $I_{\mathrm{M}}$, contrasting results have been obtained. In peripheral sympathetic neurons, no evidence could be obtained for a role of these ion channels in presynaptic transmitter release [132, 133]. However, in central synaptosomes, modulators of these ion channels were found to affect the release of various transmitters [134]. Hence, the regulation of $\mathrm{Ca}^{2+}$ channels and $\mathrm{Ca}^{2+}$ dependent $\mathrm{K}^{+}$channels via P2Y receptors will preferentially lead to changes in synaptic transmission via a presynaptic modulation of transmitter release, whereas the control of GIRKs and KCNQ channels will rather cause changes in the postsynaptic excitability. The modulation of ligand-gated ion channels may lead to pre- as well as 
postsynaptic effects depending on where the regulated ionotropic receptors are located [135]. In fact, ATP and other nucleotides acting at $\mathrm{P} 2 \mathrm{Y}$ receptors may cause both, pre- and postsynaptic effects in the central as well as peripheral nervous system.

In the cortex and hippocampus, nucleotides were found to inhibit the release of acetylcholine and noradrenaline via presynaptic sites of action. With respect to the release of dopamine, serotonin and glutamate, inhibitory as well as facilitatory presynaptic effects have been described for nucleotides in a variety of brain regions. The release of the inhibitory transmitters GABA and glycine, however, is rather enhanced than reduced by nucleotides. The precise receptor subtypes involved in these presynaptic effects remained mostly unknown, and only the facilitatory effects were evidenced to be mediated by $\mathrm{P} 2 \mathrm{X}$ receptors. Moreover, a clear-cut role of presynaptic $\mathrm{Ca}^{2+}$ or $\mathrm{K}^{+}$channels in the modulatory effects of nucleotides was not established, as reviewed by Cunha and Ribeiro [136]. In hippocampal neurons, a presynaptic P2Y receptor mediated an ATP-dependent inhibition of excitatory, but not of inhibitory, synaptic transmission via PTX-sensitive G proteins, and an inhibition of voltage-activated $\mathrm{Ca}^{2+}$ currents. However, the receptor subtype(s) involved were not further characterized [137]. In the medial habenula, a presynaptic $\mathrm{P}_{2} \mathrm{Y}_{4}$-like receptor was shown to enhance glutamate release, whereas a presumed $\mathrm{P}_{2} \mathrm{Y}_{2}$-like receptor mediated an inhibition [138]. Whether these presynaptic P2Y receptors affected transmitter release through a modulation of $\mathrm{Ca}^{2+}$ or $\mathrm{K}^{+}$ channels remained unfortunately unknown. In the prefrontal and parietal cortex, activation of a $\mathrm{P}_{2} \mathrm{Y}_{1}$-like receptor reduced glutamatergic transmission, but only the component involving NMDA receptors. Furthermore, the receptor mediated an inhibition of depolarizations caused by $N$-methylD-aspartate, but not of those induced by alpha-amino-3hydroxy-5-methyl-4-isoxazole propionic acid [123]. Thus, $\mathrm{P} 2 \mathrm{Y}$ receptor activation may also interfere with synaptic transmission via a modulation of postsynaptic ionotropic receptors.

In the periphery, in autonomic and motor neurons, release of acteylcholine or noradrenaline was also reported to be controlled by presynaptic P2X and P2Y receptors [136]. The system that has been studied in greatest detail is the sympathetic nervous system, since ATP and noradrenaline have long been known as cotransmitters there. Early evidence for presynaptic nucleotide receptors in sympathetic neurons has been obtained 20 years ago [139]. More recently, several nucleotides were found to reduce, whereas $\mathrm{P} 2$ receptor antagonists were found to enhance, noradrenaline release from the mouse vas deferens as indication of inhibitory presynaptic P2Y autoreceptors [140]. In numerous other sympathetically innervated tissues, nucleotides were also reported to inhibit transmitter release [141, 142]. For a long period of time, the $\mathrm{P} 2 \mathrm{Y}$ receptor subtypes involved in these effects remained unknown, but recent evidence suggests that $\mathrm{P} 2 \mathrm{Y}_{12}$ and/or $\mathrm{P} 2 \mathrm{Y}_{13}$ receptors mediate autoinhibition of transmitter release from sympathetic neurons [143]. In
PC12 cells which are ontogenetically related to sympathetic neurons, $\mathrm{P} 2 \mathrm{Y}_{12}$ receptors mediate an inhibition of voltage-activated $\mathrm{Ca}^{2+}$ channels (see above and [91-93]). Most recently, this effect was also observed in primary cultures of rat superior cervical ganglion neurons and it was demonstrated to mediate autoinhibition of transmitter release [96]. Hence, sympatho-effector transmission is regulated by an inhibition of voltage-activated $\mathrm{Ca}^{2+}$ channels via presynaptic $\mathrm{P}_{2} \mathrm{Y}_{12}$ receptors. In sensory neurons, in contrast, $\mathrm{P}_{2} \mathrm{Y}_{1}$ receptors mediate an inhibition of voltage-activated $\mathrm{Ca}^{2+}$ channels [144], and this effect apparently leads to reduced synaptic transmission in pain pathways and to analgesic effects [95].

However, P2Y receptor activation mediates not only inhibitory, but also excitatory effects in sensory neurons. $\mathrm{P}_{2} \mathrm{Y}_{1}$ receptor activation, in particular, was suggested to facilitate touch-induced impulse generation in sensory neurons [145], but the underlying mechanisms remained unknown. In this context, the interaction with VR1 receptors might be a relevant mechanism (see above). In autonomic neurons, $\mathrm{P}_{2} \mathrm{Y}_{1}$ receptors were also involved in excitatory postsynaptic effects: Excitatory postsynaptic potentials that were blocked by a $\mathrm{P}_{2} \mathrm{Y}_{1}$ receptor antagonist were observed in the enteric nervous system. Direct activation of these receptors caused a $\mathrm{Na}^{+}$-dependent increase in membrane conductance, but the precise ionic mechanisms were not further investigated [146]. In postganglionic sympathetic neurons, $\mathrm{P} 2 \mathrm{Y}$ receptors were also found to mediate excitatory postsynaptic effects. UTP depolarizes sympathetic ganglia and triggers transmitter release from dissociated sympathetic neurons via receptors different from those activated by ATP [147, 148]. The secretagogue action of UTP was mimicked equipotently by UDP [111, 148], and both nucleotides also caused an inhibition of $I_{\mathrm{M}}[109,111]$. The receptor involved was evidenced to be $\mathrm{P}_{2} \mathrm{Y}_{6}$. However, the stimulatory effect did not only involve the inhibition of KCNQ channels, but also an activation of protein kinase C [149].

\section{Conclusion}

The modulation of neuronal ion channels via $G$ proteincoupled receptors is a major means of adapting the responsiveness of a neuron to changes in environmental conditions [1]. Such modulatory effects have been described for virtually all known neurotransmitters and nucleotides are no exception. Within the last 15 years, 8 different $\mathrm{G}$ protein-coupled nucleotide receptors have been characterized, and numerous examples of ion channels that are regulated via one or more of these receptors are described here. Thus, aside of their functions as fast synaptic transmitters acting at $\mathrm{P} 2 \mathrm{X}$ receptors [150], nucleotides also fulfil roles as neuromodulators, as do many other classical transmitter, such as glutamate, GABA, acetylcholine, and serotonin. Thus, this summary of ion channels regulated via P2Y receptors adds ATP and related nucleotides to this list of pluripotent neurotransmitters. 


\section{Acknowledgements}

Work in the authors' laboratory is supported by grants from the Austrian Science Fund, FWF (P14951 and P15797), and from the Virologiefonds of the Medical University of Vienna.

\section{References}

1. Kaczmarek L, Levitan IB. Neuromodulation: The Biochemical Control of Neuronal Excitability. New York: Oxford University Press 1987.

2. Anderson CM, Parkinson FE. Potential signalling roles for UTP and UDP: Sources, regulation and release of uracil nucleotides. Trends Pharmacol Sci 1997; 18(10): 387-92.

3. Lazarowski ER, Boucher RC, Harden TK. Mechanisms of release of nucleotides and integration of their action as P2X- and P2Yreceptor activating molecules. Mol Pharmacol 2003; 64(4): 785-95.

4. Ralevic V, Burnstock G. Receptors for purines and pyrimidines. Pharmacol Rev 1998; 50(3): 413-92.

5. North RA. Molecular physiology of P2X receptors. Physiol Rev 2002; 82(4): 1013-67.

6. Jacobson KA, Jarvis MF, Williams M. Purine and pyrimidine (P2) receptors as drug targets. J Med Chem 2002; 45(19): 4057-93.

7. Sak K, Webb TE. A retrospective of recombinant $\mathrm{P} 2 \mathrm{Y}$ receptor subtypes and their pharmacology. Arch Biochem Biophys 2002; 397(1): 131-6.

8. Abbracchio MP, Boeynaems JM, Barnard EA et al. Characterization of the UDP-glucose receptor (re-named here the P2Y14 receptor) adds diversity to the $\mathrm{P} 2 \mathrm{Y}$ receptor family. Trends Pharmacol Sci 2003; 24(2): 52-5.

9. Inbe $\mathrm{H}$, Watanabe $\mathrm{S}$, Miyawaki $\mathrm{M}$ et al. Identification and characterization of a cell-surface receptor, P2Y15, for AMP and adenosine. J Biol Chem 2004; 279(19): 19790-9.

10. He W, Miao FJ, Lin DC et al. Citric acid cycle intermediates as ligands for orphan G-protein-coupled receptors. Nature 2004; 429(6988): 188-93.

11. Kennedy C, Qi AD, Herold CL et al. ATP, an agonist at the rat $\mathrm{P} 2 \mathrm{Y}(4)$ receptor, is an antagonist at the human $\mathrm{P} 2 \mathrm{Y}(4)$ receptor. Mol Pharmacol 2000; 57(5): 926-31.

12. White PJ, Webb TE, Boarder MR. Characterization of a $\mathrm{Ca}^{2+}$ response to both UTP and ATP at human P2Y11 receptors: Evidence for agonist-specific signaling. Mol Pharmacol 2003; 63(6): 1356-63.

13. Qi AD, Zambon AC, Insel PA, Nicholas RA. An arginine/ glutamine difference at the juxtaposition of transmembrane domain 6 and the third extracellular loop contributes to the markedly different nucleotide selectivities of human and canine P2Y11 receptors. Mol Pharmacol 2001; 60(6): 1375-82.

14. Simon J, Filippov AK, Goransson S et al. Characterization and channel coupling of the P2Y(12) nucleotide receptor of brain capillary endothelial cells. J Biol Chem 2002; 277(35): 31390-400.

15. Bodor ET, Waldo GL, Hooks SB et al. Purification and functional reconstitution of the human P2Y12 receptor. Mol Pharmacol 2003; 64(5): 1210-6.

16. Zhang FL, Luo L, Gustafson E et al. P2Y(13): Identification and characterization of a novel Galphai-coupled ADP receptor from human and mouse. J Pharmacol Exp Ther 2002; 301(2): 705-13.

17. Marteau F, Le Poul E, Communi D et al. Pharmacological characterization of the human P2Y13 receptor. Mol Pharmacol 2003; 64(1): 104-12.

18. Fumagalli M, Trincavelli L, Lecca D et al. Cloning, pharmacological characterisation and distribution of the rat G-protein-coupled P2Y(13) receptor. Biochem Pharmacol 2004; 68(1): 113-24.

19. Chambers JK, Macdonald LE, Sarau HM et al. A G protein-coupled receptor for UDP-glucose. J Biol Chem 2000; 275(15): 10767-71.

20. Nicholas RA, Watt WC, Lazarowski ER et al. Uridine nucleotide selectivity of three phospholipase $\mathrm{C}$-activating $\mathrm{P} 2$ receptors:
Identification of a UDP-selective, a UTP-selective, and an ATPand UTP-specific receptor. Mol Pharmacol 1996; 50(2): 224-9.

21. Peoples RW, Li C. Inhibition of NMDA-gated ion channels by the P2 purinoceptor antagonists suramin and reactive blue 2 in mouse hippocampal neurones. Br J Pharmacol 1998; 124(2): 400-8.

22. Galietta LJ, Falzoni S, Di Virgilio F et al. Characterization of volume-sensitive taurine- and $\mathrm{Cl}(-)$-permeable channels. Am J Physiol 1997; 273(1 Pt 1): C57-66.

23. Boyer JL, Romero-Avila T, Schachter JB, Harden TK. Identification of competitive antagonists of the P2Y1 receptor. Mol Pharmacol 1996; 50(5): 1323-9.

24. Nandanan E, Camaioni E, Jang SY et al. Structure-activity relationships of bisphosphate nucleotide derivatives as P2Y1 receptor antagonists and partial agonists. J Med Chem 1999; 42(9): 1625-38.

25. Hollopeter G, Jantzen HM, Vincent D et al. Identification of the platelet ADP receptor targeted by antithrombotic drugs. Nature 2001; 409(6817): 202-7.

26. Storey F. The P2Y12 receptor as a therapeutic target in cardiovascular disease. Platelets 2001; 12(4): 197-209.

27. Mamedova LK, Joshi BV, Gao ZG et al. Diisothiocyanate derivatives as potent, insurmountable antagonists of P2Y6 nucleotide receptors. Biochem Pharmacol 2004; 67(9): 1763-70.

28. Communi D, Gonzalez NS, Detheux M et al. Identification of a novel human ADP receptor coupled to G(i). J Biol Chem 2001; 276(44): 41479-85.

29. Moore D, Chambers J, Waldvogel $\mathrm{H}$ et al. Regional and cellular distribution of the P2Y(1) purinergic receptor in the human brain: Striking neuronal localisation. J Comp Neurol 2000; 421(3): 374 84.

30. Moore DJ, Chambers JK, Wahlin JP et al. Expression pattern of human P2Y receptor subtypes: A quantitative reverse transcriptionpolymerase chain reaction study. Biochim Biophys Acta 2001; 1521(1-3): 107-19.

31. Moran-Jimenez MJ, Matute C. Immunohistochemical localization of the P2Y(1) purinergic receptor in neurons and glial cells of the central nervous system. Brain Res Mol Brain Res 2000; 78(1-2): $50-8$.

32. Zhang FL, Luo L, Gustafson $\mathrm{E}$ et al. ADP is the cognate ligand for the orphan $\mathrm{G}$ protein-coupled receptor SP1999. J Biol Chem 2001; 276(11): 8608-15.

33. Communi D, Govaerts C, Parmentier M, Boeynaems JM. Cloning of a human purinergic P2Y receptor coupled to phospholipase C and adenylyl cyclase. J Biol Chem 1997; 272(51): 31969-73.

34. Cantrell AR, Catterall WA. Neuromodulation of $\mathrm{Na}^{+}$channels: An unexpected form of cellular plasticity. Nat Rev Neurosci 2001; 2(6): $397-407$

35. Cantrell AR, Smith RD, Goldin AL et al. Dopaminergic modulation of sodium current in hippocampal neurons via cAMP-dependent phosphorylation of specific sites in the sodium channel alpha subunit. J Neurosci 1997; 17(19): 7330-8.

36. Cantrell AR, Scheuer T, Catterall WA. Voltage-dependent neuromodulation of $\mathrm{Na}^{+}$channels by D1-like dopamine receptors in rat hippocampal neurons. J Neurosci 1999; 19(13): 5301-10.

37. Cantrell AR, Ma JY, Scheuer T, Catterall WA. Muscarinic modulation of sodium current by activation of protein kinase $\mathrm{C}$ in rat hippocampal neurons. Neuron 1996; 16(5): 1019-26.

38. Mittmann T, Alzheimer C. Muscarinic inhibition of persistent $\mathrm{Na}^{+}$ current in rat neocortical pyramidal neurons. J Neurophysiol 1998; 79(3): 1579-82.

39. Carr DB, Sesack SR. Hippocampal afferents to the rat prefrontal cortex: Synaptic targets and relation to dopamine terminals. J Comp Neurol 1996; 369(1): 1-15.

40. Gold MS, Reichling DB, Shuster MJ, Levine JD. Hyperalgesic agents increase a tetrodotoxin-resistant $\mathrm{Na}^{+}$current in nociceptors. Proc Natl Acad Sci USA 1996; 93(3): 1108-12.

41. England S, Bevan S, Docherty RJ. PGE2 modulates the tetrodotoxin-resistant sodium current in neonatal rat dorsal root ganglion neurones via the cyclic AMP-protein kinase A cascade. J Physiol 1996; 495(Pt 2): 429-40. 
42. Catterall WA, Striessnig J, Snutch TP, Perez-Reyes E. International Union of Pharmacology: XL. Compendium of voltage-gated ion channels: Calcium channels. Pharmacol Rev 2003; 55(4): 579-81.

43. Hille B. Modulation of ion-channel function by G-protein-coupled receptors. Trends Neurosci 1994; 17(12): 531-6.

44. Ikeda SR, Dunlap K. Voltage-dependent modulation of N-type calcium channels: Role of $G$ protein subunits. Adv Second Messenger Phosphoprot Res 1999; 33: 131-51.

45. Dolphin AC. L-type calcium channel modulation. Adv Second Messenger Phosphoprot Res 1999; 33: 153-77.

46. Dolphin AC. G protein modulation of voltage-gated calcium channels. Pharmacol Rev 2003; 55(4): 607-27.

47. Diverse-Pierluissi M, Dunlap K. Distinct, convergent second messenger pathways modulate neuronal calcium currents. Neuron 1993; 10(4): 753-60.

48. Boehm S, Huck S, Freissmuth M. Involvement of a phorbol esterinsensitive protein kinase $\mathrm{C}$ in the alpha2-adrenergic inhibition of voltage-gated calcium current in chick sympathetic neurons. J Neurosci 1996; 16(15): 4596-603.

49. Kammermeier PJ, Ruiz-Velasco V, Ikeda SR. A voltage-independent calcium current inhibitory pathway activated by muscarinic agonists in rat sympathetic neurons requires both Galpha q/11 and Gbeta gamma. J Neurosci 2000; 20(15): 5623-9.

50. Haley JE, Delmas P, Offermanns S et al. Muscarinic inhibition of calcium current and $\mathrm{M}$ current in Galpha q-deficient mice. J Neurosci 2000; 20(11): 3973-9.

51. Gutman GA, Chandy KG, Adelman JP et al. International Union of Pharmacology: XLI. Compendium of voltage-gated ion channels: Potassium channels. Pharmacol Rev 2003; 55(4): 583-6.

52. Stanfield PR, Nakajima S, Nakajima Y. Constitutively active and G-protein coupled inward rectifier $\mathrm{K}^{+}$channels: Kir2.0 and Kir3.0. Rev Physiol Biochem Pharmacol 2002; 145: 47-179.

53. Peleg S, Varon D, Ivanina T et al. G(alpha)(i) controls the gating of the $\mathrm{G}$ protein-activated $\mathrm{K}(+)$ channel, GIRK. Neuron 2002; 33(1): 87-99.

54. Benians A, Leaney JL, Milligan G, Tinker A. The dynamics of formation and action of the ternary complex revealed in living cells using a G-protein-gated $\mathrm{K}^{+}$channel as a biosensor. J Biol Chem 2003; 278(12): 10851-8.

55. Doupnik CA, Davidson N, Lester HA, Kofuji P. RGS proteins reconstitute the rapid gating kinetics of gbetagamma-activated inwardly rectifying $\mathrm{K}^{+}$channels. Proc Natl Acad Sci USA 1997; 94(19): 10461-6.

56. Huang CL, Feng S, Hilgemann DW. Direct activation of inward rectifier potassium channels by PIP2 and its stabilization by Gbetagamma. Nature 1998; 391(6669): 803-6.

57. Rebecchi MJ, Pentyala SN. Structure, function, and control of phosphoinositide-specific phospholipase C. Physiol Rev 2000; 80(4): 1291-335.

58. Mark MD, Herlitze S. G-protein mediated gating of inward-rectifier $\mathrm{K}^{+}$channels. Eur J Biochem 2000; 267(19): 5830-6.

59. Mullner C, Vorobiov D, Bera AK et al. Heterologous facilitation of G protein-activated $\mathrm{K}(+)$ channels by beta-adrenergic stimulation via cAMP-dependent protein kinase. J Gen Physiol 2000; 115(5): 547-58.

60. Robbins J. KCNQ potassium channels: Physiology, pathophysiology, and pharmacology. Pharmacol Ther 2001; 90(1): 1-19.

61. Brown DA. Slow cholinergic excitation - a mechanism for increasing neuronal excitability. TINS 1983; 6: 302-7.

62. Marrion NV. Control of M-current. Annu Rev Physiol 1997; 59: 483-504.

63. Haley JE, Abogadie FC, Delmas P et al. The alpha subunit of Gq contributes to muscarinic inhibition of the M-type potassium current in sympathetic neurons. J Neurosci 1998; 18(12): 4521-31.

64. Suh BC, Hille B. Recovery from muscarinic modulation of $\mathrm{M}$ current channels requires phosphatidylinositol 4,5-bisphosphate synthesis. Neuron 2002; 35(3): 507-20.

65. Jones S, Brown DA, Milligan $G$ et al. Bradykinin excites rat sympathetic neurons by inhibition of $M$ current through a mechanism involving B2 receptors and $G$ alpha $q / 11$. Neuron 1995; 14(2): 399-405.
66. Haley JE, Abogadie FC, Fernandez-Fernandez JM et al. Bradykinin, but not muscarinic, inhibition of M-current in rat sympathetic ganglion neurons involves phospholipase C-beta 4. J Neurosci 2000; 20(21): RC105.

67. Cruzblanca H, Koh DS, Hille B. Bradykinin inhibits M current via phospholipase $\mathrm{C}$ and $\mathrm{Ca}^{2+}$ release from IP3-sensitive $\mathrm{Ca}^{2+}$ stores in rat sympathetic neurons. Proc Natl Acad Sci USA 1998; 95(12): 7151-6.

68. Selyanko AA, Brown DA. Intracellular calcium directly inhibits potassium $M$ channels in excised membrane patches from rat sympathetic neurons. Neuron 1996; 16(1): 151-62.

69. Role LW. Substance P modulation of acetylcholine-induced currents in embryonic chicken sympathetic and ciliary ganglion neurons. Proc Natl Acad Sci USA 1984; 81(9): 2924-8.

70. Valenta DC, Downing JE, Role LW. Peptide modulation of ACh receptor desensitization controls neurotransmitter release from chicken sympathetic neurons. J Neurophysiol 1993; 69(3): 928-42.

71. Tan W, Du C, Siegelbaum SA, Role LW. Modulation of nicotinic AChR channels by prostaglandin E2 in chick sympathetic ganglion neurons. J Neurophysiol 1998; 79(2): 870-8.

72. Liu DM, Cuevas J, Adams DJ. VIP and PACAP potentiation of nicotinic ACh-evoked currents in rat parasympathetic neurons is mediated by G-protein activation. Eur J Neurosci 2000; 12(7): 2243-51.

73. Norenberg $\mathrm{W}$, Bek $\mathrm{M}$, Limberger $\mathrm{N}$ et al. Inhibition of nicotinic acetylcholine receptor channels in bovine adrenal chromaffin cells by Y3-type neuropeptide Y receptors via the adenylate cyclase/ protein kinase A system. Naunyn-Schmiedeberg's Arch Pharmacol 1995; 351(4): 337-47.

74. Yevenes GE, Peoples RW, Tapia JC et al. Modulation of glycineactivated ion channel function by G-protein betagamma subunits. Nat Neurosci 2003; 6(8): 819-24.

75. Ahmadi S, Lippross S, Neuhuber WL, Zeilhofer HU. PGE(2) selectively blocks inhibitory glycinergic neurotransmission onto rat superficial dorsal horn neurons. Nat Neurosci 2002; 5(1): 34-40.

76. Lu WY, Xiong ZG, Lei S et al. G-protein-coupled receptors act via protein kinase $\mathrm{C}$ and $\mathrm{Src}$ to regulate NMDA receptors. Nat Neurosci 1999; 2(4): 331-8.

77. Kotecha SA, Oak JN, Jackson MF et al. A D2 class dopamine receptor transactivates a receptor tyrosine kinase to inhibit NMDA receptor transmission. Neuron 2002; 35(6): 1111-22.

78. Lee FJ, Xue S, Pei L et al. Dual regulation of NMDA receptor functions by direct protein-protein interactions with the dopamine D1 receptor. Cell 2002; 111(2): 219-30.

79. Balasubramanian S, Teissere JA, Raju DV, Hall RA. Heterooligomerization between GABAA and GABAB receptors regulates GABAB receptor trafficking. J Biol Chem 2004; 279(18): 18840-50.

80. Joo Choi E, Hong MP, Kyoo Shin Y et al. ATP modulation of sodium currents in rat dorsal root ganglion neurons. Brain Res 2003; 968(1): 15-25

81. El-Sherif Y, Wieraszko A, Banerjee P, Penington NJ. ATP modulates $\mathrm{Na}+$ channel gating and induces a non-selective cation current in a neuronal hippocampal cell line. Brain Res 2001; 904(2): 307-17.

82. Dunlap K, Fischbach GD. Neurotransmitters decrease the calcium component of sensory neurone action potentials. Nature 1978; 276(5690): 837-9.

83. Dunlap K, Fischbach GD. Neurotransmitters decrease the calcium conductance activated by depolarization of embryonic chick sensory neurones. J Physiol 1981; 317: 519-35.

84. Diverse-Pierluissi M, Dunlap K, Westhead EW. Multiple actions of extracellular ATP on calcium currents in cultured bovine chromaffin cells. Proc Natl Acad Sci USA 1991; 88(4): 1261-5.

85. Gandia L, Garcia AG, Morad M. ATP modulation of calcium channels in chromaffin cells. J Physiol 1993; 470: 55-72.

86. Currie KP, Fox AP. ATP serves as a negative feedback inhibitor of voltage-gated $\mathrm{Ca}^{2+}$ channel currents in cultured bovine adrenal chromaffin cells. Neuron 1996; 16(5): 1027-36.

87. Powell AD, Teschemacher AG, Seward EP. P2Y purinoceptors inhibit exocytosis in adrenal chromaffin cells via modulation of 
voltage-operated calcium channels. J Neurosci 2000; 20(2): 606-16.

88. Lim W, Kim SJ, Yan HD, Kim J. $\mathrm{Ca}^{2+}$-channel-dependent and -independent inhibition of exocytosis by extracellular ATP in voltage-clamped rat adrenal chromaffin cells. Pflugers Arch 1997; 435(1): 34-42.

89. Elmslie KS. Calcium current modulation in frog sympathetic neurones: Multiple neurotransmitters and G proteins. J Physiol 1992; 451: 229-46.

90. Filippov AK, Brown DA. Activation of nucleotide receptors inhibits high-threshold calcium currents in NG108-15 neuronal hybrid cells. Eur J Neurosci 1996; 8(6): 1149-55.

91. Vartian N, Boehm S. P2Y receptor-mediated inhibition of voltageactivated $\mathrm{Ca}(2+)$ currents in PC12 cells. Eur J Neurosci 2001; 13(5): 899-908.

92. Kulick MB, von Kugelgen I. P2Y-receptors mediating an inhibition of the evoked entry of calcium through N-type calcium channels at neuronal processes. J Pharmacol Exp Ther 2002; 303(2): 520-6.

93. Kubista H, Lechner SG, Wolf AM, Boehm S. Attenuation of the $\mathrm{P} 2 \mathrm{Y}$ receptor-mediated control of neuronal $\mathrm{Ca}^{2+}$ channels in PC12 cells by antithrombotic drugs. Br J Pharmacol 2003; 138(2): 343-50.

94. Abe M, Endoh T, Suzuki T. Extracellular ATP-induced calcium channel inhibition mediated by $\mathrm{P} 1 / \mathrm{P} 2 \mathrm{Y}$ purinoceptors in hamster submandibular ganglion neurons. Br J Pharmacol 2003; 138(8): 1535-43.

95. Gerevich Z, Borvendeg SJ, Schroder W et al. Inhibition of N-type voltage-activated calcium channels in rat dorsal root ganglion neurons by $\mathrm{P} 2 \mathrm{Y}$ receptors is a possible mechanism of ADP-induced analgesia. J Neurosci 2004; 24(4): 797-807.

96. Lechner SG, Dorostkar MM, Mayer M et al. Autoinhibition of transmitter release from $\mathrm{PC} 12$ cells and sympathetic neurons through a P2Y12 receptor-mediated inhibition of voltage-gated $\mathrm{Ca}^{2+}$ channels. Eur $\mathrm{J}$ Neurosci (in press).

97. Scamps F, Vassort G. Pharmacological profile of the ATP-mediated increase in L-type calcium current amplitude and activation of a non-specific cationic current in rat ventricular cells. Br J Pharmacol 1994; 113(3): 982-6.

98. Dave S, Mogul DJ. ATP receptor activation potentiates a voltagedependent Ca channel in hippocampal neurons. Brain Res 1996; 715(1-2): 208-16.

99. Filippov AK, Selyanko AA, Robbins J, Brown DA. Activation of nucleotide receptors inhibits $\mathrm{M}$-type $\mathrm{K}$ current [IK(M)] in neuroblastoma $\times$ glioma hybrid cells. Pflugers Arch 1994; 429(2): $223-$ 30.

100. Filippov AK, Webb TE, Barnard EA, Brown DA. P2Y2 nucleotide receptors expressed heterologously in sympathetic neurons inhibit both N-type $\mathrm{Ca}^{2+}$ and M-type $\mathrm{K}^{+}$currents. J Neurosci 1998; 18(14): 5170-9.

101. Filippov AK, Webb TE, Barnard EA, Brown DA. Dual coupling of heterologously-expressed rat P2Y6 nucleotide receptors to N-type $\mathrm{Ca}^{2+}$ and M-type $\mathrm{K}^{+}$currents in rat sympathetic neurones. $\mathrm{Br} \mathrm{J}$ Pharmacol 1999; 126(4): 1009-17.

102. Filippov AK, Brown DA, Barnard EA. The P2Y(1) receptor closes the $\mathrm{N}$-type $\mathrm{Ca}(2+)$ channel in neurones, with both adenosine triphosphates and diphosphates as potent agonists. Br J Pharmacol 2000; 129(6): 1063-6.

103. Brown DA, Filippov AK, Barnard EA. Inhibition of potassium and calcium currents in neurones by molecularly-defined P2Y receptors. J Auton Nerv Syst 2000; 81(1-3): 31-6.

104. Filippov AK, Simon J, Barnard EA, Brown DA. Coupling of the nucleotide P2Y4 receptor to neuronal ion channels. Br J Pharmacol 2003; 138(2): 400-6.

105. Adams PR, Brown DA, Constanti A. Pharmacological inhibition of the M-current. J Physiol 1982; 332: 223-62.

106. Akasu T, Hirai K, Koketsu K. Modulatory actions of ATP on membrane potentials of bullfrog sympathetic ganglion cells. Brain Res 1983; 258(2): 313-7.

107. Lopez HS, Adams PR. A G protein mediates the inhibition of the voltage-dependent potassium $\mathrm{M}$ current by muscarine, LHRH, substance $\mathrm{P}$ and UTP in bullfrog sympathetic neurons. Eur J Neurosci 1989; 1(5): 529-42.

108. Tokimasa T, Akasu T. ATP regulates muscarine-sensitive potassium current in dissociated bull-frog primary afferent neurones. J Physiol 1990; 426: 241-64.

109. Boehm S. Selective inhibition of M-type potassium channels in rat sympathetic neurons by uridine nucleotide preferring receptors. $\mathrm{Br} \mathrm{J}$ Pharmacol 1998; 124(6): 1261-9.

110. Bofill-Cardona E, Vartian N, Nanoff $\mathrm{C}$ et al. Two different signaling mechanisms involved in the excitation of rat sympathetic neurons by uridine nucleotides. Mol Pharmacol 2000; 57(6): $1165-72$.

111. Norenberg W, von Kugelgen I, Meyer A et al. M-type $\mathrm{K}^{+}$currents in rat cultured thoracolumbar sympathetic neurones and their role in uracil nucleotide-evoked noradrenaline release. $\mathrm{Br} \mathrm{J}$ Pharmacol 2000; 129(4): 709-23.

112. Meng H, Sakakibara M, Nakazawa H, Tokimasa T. Pyridoxalphosphate-6-azophenyl-2', $4^{\prime}$-disulfonic acid can antagonize the purinoceptor-mediated inhibition of M-current in bullfrog sympathetic neurons. Neurosci Lett 2003; 337(2): 93-6.

113. Ikeuchi $\mathrm{Y}$, Nishizaki T. ATP-evoked potassium currents in rat striatal neurons are mediated by a P2 purinergic receptor. Neurosci Lett 1995; 190(2): 89-92.

114. Ikeuchi Y, Nishizaki T. The P2Y purinoceptor-operated potassium channel is possibly regulated by the beta gamma subunits of a pertussis toxin-insensitive G-protein in cultured rat inferior colliculus neurons. Biochem Biophys Res Commun 1995; 214(2): 589-96.

115. Nishizaki T, Ikeuchi Y. Adenosine evokes potassium currents by protein kinase $\mathrm{C}$ activated via a novel signaling pathway in superior colliculus neurons. FEBS Lett 1996; 378(1): 1-6.

116. Ikeuchi Y, Nishizaki T. P2 purinoceptor-operated potassium channel in rat cerebellar neurons. Biochem Biophys Res Commun 1996; 218(1): 67-71.

117. Ikeuchi Y, Nishizaki T, Okada Y. Repetitive applications of ATP potentiate potassium current by $\mathrm{Ca}^{2+} /$ calmodulin kinase in cultured rat hippocampal neurons. Neurosci Lett 1996; 203(2): 115-8.

118. Nakazawa K, Inoue K. ATP reduces voltage-activated $\mathrm{K}^{+}$current in cultured rat hippocampal neurons. Pflugers Arch 1994; 429(1): $143-5$.

119. Brown P, Dale N. Modulation of $\mathrm{K}(+)$ currents in Xenopus spinal neurons by $\mathrm{p} 2 \mathrm{y}$ receptors: A role for ATP and ADP in motor pattern generation. J Physiol 2002; 540(Pt 3): 843-50.

120. Mark MD, Ruppersberg JP, Herlitze S. Regulation of GIRK channel deactivation by Galpha(q) and Galpha(i/o) pathways. Neuropharmacology 2000; 39(12): 2360-73.

121. Mosbacher J, Maier R, Fakler B et al. P2Y receptor subtypes differentially couple to inwardly-rectifying potassium channels. FEBS Lett 1998; 436(1): 104-10.

122. Wirkner K, Koles L, Thummler S et al. Interaction between P2Y and NMDA receptors in layer $\mathrm{V}$ pyramidal neurons of the rat prefrontal cortex. Neuropharmacology 2002; 42(4): 476-88.

123. Luthardt J, Borvendeg SJ, Sperlagh B et al. P2Y(1) receptor activation inhibits NMDA receptor-channels in layer $\mathrm{V}$ pyramidal neurons of the rat prefrontal and parietal cortex. Neurochem Int 2003; 42(2): 161-72.

124. Ortinau S, Laube B, Zimmermann H. ATP inhibits NMDA receptors after heterologous expression and in cultured hippocampal neurons and attenuates NMDA-mediated neurotoxicity. J Neurosci 2003; 23(12): 4996-5003.

125. Tominaga M, Wada M, Masu M. Potentiation of capsaicin receptor activity by metabotropic ATP receptors as a possible mechanism for ATP-evoked pain and hyperalgesia. Proc Natl Acad Sci USA 2001; 98(12): 6951-6.

126. Moriyama $\mathrm{T}$, Iida $\mathrm{T}$, Kobayashi $\mathrm{K}$ et al. Possible involvement of P2Y2 metabotropic receptors in ATP-induced transient receptor potential vanilloid receptor 1-mediated thermal hypersensitivity. J Neurosci 2003; 23(14): 6058-62.

127. Vial C, Tobin AB, Evans RJ. G-protein-coupled receptor regulation of $\mathrm{P} 2 \mathrm{X}(1)$ receptors does not involve direct channel phosphorylation. Biochem J 2004; 382(Pt 1): 101-10. 
128. Stevens CF. Presynaptic function. Curr Opin Neurobiol 2004; 14(3): 341-5

129. Meir A, Ginsburg S, Butkevich A et al. Ion channels in presynaptic nerve terminals and control of transmitter release. Physiol Rev 1999; 79(3): 1019-88.

130. Dodson PD, Forsythe ID. Presynaptic $\mathrm{K}^{+}$channels: Electrifying regulators of synaptic terminal excitability. Trends Neurosci 2004; 27(4): 210-7.

131. Luscher C, Jan LY, Stoffel M et al. G protein-coupled inwardly rectifying $\mathrm{K}^{+}$channels (GIRKs) mediate postsynaptic but not presynaptic transmitter actions in hippocampal neurons. Neuron 1997; 19(3): 687-95.

132. Kristufek D, Koth G, Motejlek A et al. Modulation of spontaneous and stimulation-evoked transmitter release from rat sympathetic neurons by the cognition enhancer linopirdine: Insights into its mechanisms of action. J Neurochem 1999; 72(5): 2083-91.

133. Lechner SG, Mayer M, Boehm S. Activation of M1 muscarinic receptors triggers transmitter release from rat sympathetic neurons through an inhibition of M-type $\mathrm{K}^{+}$channels. J Physiol 2003; 553(Pt 3): 789-802.

134. Martire M, Castaldo P, D'Amico $\mathrm{M}$ et al. $\mathrm{M}$ channels containing KCNQ2 subunits modulate norepinephrine, aspartate, and GABA release from hippocampal nerve terminals. J Neurosci 2004; 24(3): 592-7.

135. Engelman HS, MacDermott AB. Presynaptic ionotropic receptors and control of transmitter release. Nat Rev Neurosci 2004; 5(2): 135-45.

136. Cunha RA, Ribeiro JA. ATP as a presynaptic modulator. Life Sci 2000; 68(2): 119-37.

137. Zhang JM, Wang HK, Ye CQ et al. ATP released by astrocytes mediates glutamatergic activity-dependent heterosynaptic suppression. Neuron 2003; 40(5): 971-82.

138. Price GD, Robertson SJ, Edwards FA. Long-term potentiation of glutamatergic synaptic transmission induced by activation of presynaptic $\mathrm{P} 2 \mathrm{Y}$ receptors in the rat medial habenula nucleus. Eur J Neurosci 2003; 17(4): 844-50.
139. Stjarne L, Astrand P. Relative pre- and postjunctional roles of noradrenaline and adenosine 5 '-triphosphate as neurotransmitters of the sympathetic nerves of guinea-pig and mouse vas deferens. Neuroscience 1985; 14(3): 929-46.

140. von Kugelgen I, Kurz K, Starke K. Axon terminal P2-purinoceptors in feedback control of sympathetic transmitter release. Neuroscience 1993; 56(2): 263-7.

141. Boehm S. Signaling via nucleotide receptors in the sympathetic nervous system. Drug News Perspect 2003; 16(3): 141-8.

142. Boehm S, Kubista H. Fine tuning of sympathetic transmitter release via ionotropic and metabotropic presynaptic receptors. Pharmacol Rev 2002; 54(1): 43-99.

143. Queiroz G, Talaia C, Goncalves J. ATP modulates noradrenaline release by activation of inhibitory $\mathrm{P} 2 \mathrm{Y}$ receptors and facilitatory $\mathrm{P} 2 \mathrm{X}$ receptors in the rat vas deferens. J Pharmacol Exp Ther 2003; 307(2): 809-15.

144. Borvendeg SJ, Gerevich Z, Gillen C, Illes P. P2Y receptormediated inhibition of voltage-dependent $\mathrm{Ca}^{2+}$ channels in rat dorsal root ganglion neurons. Synapse 2003; 47(2): 159-61.

145. Nakamura F, Strittmatter SM. P2Y1 purinergic receptors in sensory neurons: Contribution to touch-induced impulse generation. Proc Natl Acad Sci USA 1996; 93(19): 10465-70.

146. $\mathrm{Hu} \mathrm{HZ}$, Gao N, Zhu MX et al. Slow excitatory synaptic transmission mediated by $\mathrm{P} 2 \mathrm{Y} 1$ receptors in the guinea-pig enteric nervous system. J Physiol 2003; 550(Pt 2): 493-504.

147. Connolly GP, Harrison PJ, Stone TW. Action of purine and pyrimidine nucleotides on the rat superior cervical ganglion. $\mathrm{Br} \mathrm{J}$ Pharmacol 1993; 110(4): 1297-304.

148. Boehm S, Huck S, Illes P. UTP- and ATP-triggered transmitter release from rat sympathetic neurones via separate receptors. $\mathrm{Br} \mathrm{J}$ Pharmacol 1995; 116(5): 2341-3.

149. Vartian N, Moskvina E, Scholze T et al. UTP evokes noradrenaline release from rat sympathetic neurons by activation of protein kinase C. J Neurochem 2001; 77(3): 876-85.

150. Robertson SJ, Ennion SJ, Evans RJ, Edwards FA. Synaptic P2X receptors. Curr Opin Neurobiol 2001; 11(3): 378-86. 